\title{
DETERMINANTS OF OVERINDEBTEDNESS AMONG MICROFINANCE BORROWERS: A POVERTY LINE-BASED APPROACH
}

\author{
Sunil Puliyakot
}

Borrower overindebtedness is a serious issue faced by the microfinance industry globally. In that regard, the purpose of the present article is to identify the extent and determinants of borrower overindebtedness among microfinance borrowers.

For this study, the concept of overindebtedness is approached with the help of a scientifically estimated poverty line level of income by a government agency, and then the results are compared with the World Bank recommended poverty line of $\$ 1.90$ per capita per day. A quantitative methodology is followed using a survey design covering 210 borrowing households in two districts from the state of Tamil Nadu in India.

The findings of the study indicate that approximately 57 per cent of the sample respondents are overindebted. Results of the binomial logistic regression show that adverse economic shocks, low household income, number of credit arrangements contracted by the household and quantum of borrowing from informal sources increase the likelihood of a household being overindebted. Comparison with the World Bank recommended poverty line shows large similarities.

Accordingly, the study points to the need to prioritize income generation schemes rather than credit distribution schemes as an instrument of social policy.

JEL classification: C93, C51, D14, D92, I31

Keywords: microfinance, micro credit; overindebtedness, poverty line

Sunil Puliyakot, Associate Professor, Rajagiri Business School, Rajagiri Valley (PO), Kochi, Kerala, India (email: sunil@rajagiri.edu). 


\section{INTRODUCTION}

The microfinance industry has expanded at a rapid pace globally since the turn of the century, aided by a favourable policy and institutional environment. Industry sources estimate that as at the end of 2013, approximately 3,000 microfinance institutions around the world had reached out to 211 million borrowers (Microcredit Summit Campaign, 2015). This impressive growth has not been achieved without its own trade-offs and risk factors (Reichert, 2018). Significant among them is the situation of overindebtedness faced by the borrowing households (Centre for the Study of Financial Innovation, 2012; Schicks and Rosenberg, 2011; Guérin, MorvantRoux and Villarreal, 2013).

Rigorous and systematic studies of the situation of overindebtedness, which facilitate firm and effective policy intervention, have yet to emerge, barring a couple of exceptions (Schicks, 2013a; Ray, Mahapatra and Nath, 2019). Researchers encounter various constraints in designing and implementing scientifically sound studies, primarily because of the measurement issues associated with the concept of overindebtedness. The multifaceted nature of the concept inhibits use of simple and straightforward measures to represent it (Betti and others, 2007; European Commission, 2008).

For the present paper, this issue is addressed with a unique feature of the Indian microfinance market, namely the availability of a scientifically estimated poverty line primarily intended to facilitate policy implementation by the government. Poverty line represents the estimated minimum level of income needed to secure the necessities of life. For this paper, borrowing households whose disposable income after meeting the monthly debt repayment commitments falls below poverty line income are deemed to be overindebted. This is the first attempt to analyse overindebtedness using an objective and publicly available measure, such as the poverty line level of income.

Using a unique data set of 210 borrowing households spread across two districts in Tamil Nadu, a state in Southern India, it was found that approximately 57 per cent of the borrowing households were overindebted. Among the factors that caused a household to be overindebted, household income, adverse economic shocks, number of credit arrangements and borrowing from informal sources were found to be significant determinants. Borrowings from microfinance institutions and the fees and interest charged by them were not found to be significantly influencing overindebtedness.

The rest of the paper is divided as follows. The next section gives a brief review of the literature dealing with overindebtedness, providing a rationale for the choice of the measure of identification of overindebtedness. In the subsequent section, the hypotheses, the empirical model and the variable definitions are set out, followed 
by a description of the sample and the data. A discussion of the results of empirical tests follows that section and the last section concludes with policy implications and limitations of the study.

\section{LITERATURE REVIEW AND A CONCEPTUAL FRAMEWORK FOR OVERINDEBTEDNESS}

Attempts to define overindebtedness have involved reviewing the concept from theoretical and empirical perspectives. From a theoretical perspective, theories explaining consumption behaviour do not allow any level of borrowing to be termed as overindebtedness (Betti and others, 2007). Later research on models, however, allowing for departure from rationality of agents and complete information, permits market outcomes, such as overindebtedness. Poverty impeding cognitive function (Mani and others, 2013), problems with self-control (Schelling, 1984), tunnel vision (Williams, 1985) and excessive present bias (Frederick, Loewenstein and O'Donoghue, 2002) are examples of models predicting deviations from complete rationality.

From the empirical perspective, the concept of overindebtedness has been investigated widely from the perspective of consumer finance markets of the United States of America and Europe (Rowlinson and Kempson, 1994; Kempson, 2002; Haas, 2006; Dickerson, 2008). One of the main challenges faced by these studies is to identify an appropriate measure to represent the concept. In studies involving consumer finance, borrower overindebtedness is normally represented by a set of borrowing-related measures, such as total borrowing, borrowing to income ratio, repayment to income ratio or debt to asset ratio (Betti and others, 2007; Disney, Bridges and Gathergood, 2010).

Early studies focusing on the overindebtedness of microfinance borrowers have tried to look at the concept from different viewpoints. For instance, for some of them, a household is considered to be overindebted if it cannot meet its payment obligations arising from all the debt contracts that the household has entered into (Pytkowska and Spannuth, 2011; 2012; Maurer and Pytkowska, 2011). Schicks (2013b) defines a borrower as being overindebted if the borrower has serious problems to repay loans. To study the overindebtedness problem of Bangladesh microfinance borrowers, Khandker, Faruqee and Samad (2013) use thresholds based on ratios of household finances of the borrowers to indicate the levels of indebtedness. Indebtedness beyond a threshold are considered to reflect the state of overindebtedness. All of the abovementioned studies lack an objective benchmark for defining overindebtedness. Some studies use client default as an outcome variable representing overindebtedness (OXERA Consulting, 2004). This measure may not be very relevant in the case of microfinance borrowers, as there are very few default cases reported in the field, except in a crisis situation (Mader, 2013). 
For this paper, measuring overindebtedness is predicated on whether the monthly repayment obligations of a borrowing household push the household below the poverty line level of consumption. To ensure the effectiveness of targeted subsidies for the poor, the Government of India tries to identify a certain level of monthly per capita consumption expenditure that can meet the expenses required for the absolute necessities of life and livelihood. Households earning an income below this monthly per capita consumption expenditure level are deemed to be living below the poverty line. The latest attempt in a series starting from 1979 has put this expenditure at 972 Indian rupee (Rs) (\$12) in rural areas and Rs 1,407 in urban areas based on the 2011/12 financial year prices (India Planning Commission, 2014).

This poverty line threshold is used in this paper to identify whether a household is overindebted. The identification strategy is based on the condition that after deducting the loan repayments, does the monthly disposable income of the households fall below the income required to maintain the poverty line level of consumption, adjusted for inflation? If it falls below the level, the household is considered to be overindebted, otherwise not. This approach ensures objectivity of measurement of overindebtedness because it captures the negative consequences of having to live below the poverty line by virtue of having excessive debt. Other measures of overindebtedness use thresholds of ratios based on income or expenditure, but they may not capture this consequence, if the denominator is large. Subjective measures of overindebtedness based on experiences of sacrifices may be hampered by the weakness of differences in borrowers' perceptions as to what constitutes a sacrifice and how acceptable those sacrifices are, based on local contexts and individual borrower characteristics. The identification strategy attempts to build on the above.

\section{HYPOTHESIS, VARIABLES AND EMPIRICAL MODEL FOR ESTIMATION}

\section{Hypothesis}

In a survey of evidence related to overindebtedness among microfinance borrowers in various rapidly growing markets of microfinance, Schicks and Rosenberg (2011) identify three broad categories of factors affecting borrower indebtedness, namely environmental factors, borrower-related factors and lender-related factors.

Among the environmental factors, adverse expenditure, and income shocks and uncertainty with respect to the income sources of the borrowers are expected to have a significant influence on levels of indebtedness. In studies of indebtedness using the British Household Panel Survey, Disney, Bridges and Gathergood (2008) allude to the role of adverse economic shocks in developing overindebtedness. Perhaps 
the most direct influence of adverse shocks on indebtedness has been identified by Khandker, Faruqee, and Samad (2013), in which the authors find a significant marginal influence of adverse shocks (such as death of a family member, losses in an income-generation activity, natural calamities and other types of financial losses) on various levels of indebtedness of the borrower households. Hulme (2007) also posits that because of circumstances beyond their control (such as sickness, flood, drought and theft), lack of skills and knowledge or taking bad decisions, a proportion of poor borrowers encounters great difficulties in repaying loans.

In the consumer finance literature, the strong relationship between the situational aspects of the individual's life and his or her risk for developing indebtedness has been confirmed by Stone and Maury (2006). Khalily and Faridi (2011) supports this argument by pointing out a high correlation between income shocks and multiple borrowing among Bangladeshi borrowers. Evidences for uncertain incomes resulting in higher levels of debt among microfinance borrowers are also given in Pytkowska and Spannuth $(2011 ; 2012)$, and Schicks (2013a).

Accordingly, hypotheses related to environmental factors can be the following:

H1a: Occurrence of adverse economic shocks in the borrower households during the previous $\mathbf{1 2}$ months will be positively and significantly associated with overindebtedness.

\section{H1b: Income uncertainty of the borrower households will be positively and significantly associated with overindebtedness.}

Significant association has been found between low income and overindebtedness in consumer finance and microfinance literature. Some of the examples are the following: Bridges and Disney (2004); and Disney, Bridges and Gathergood (2008). In the specific context of microfinance, a negative relationship between income and repayment problems was observed by Al Mamun and others (2011) and Oke, Adeyemo and Agbonlahor (2007). Similarly, evidence of the influence of household wealth in indebtedness is given by Disney, Bridges and Gathergood (2010), Godquin (2004), Sharma and Zeller (1997) and Schicks (2013a). A significant portion of household wealth in the case of most microfinance borrowers constitutes a residential house property in which the borrowing household resides. This property can serve as collateral for informal borrowing, thereby increasing the borrowing capacity of the household. The resulting increase in borrowing can, therefore, lead to overindebtedness.

A distinction needs to be made between adverse economic shocks and expected large lump-sum shocks. The former is totally unplanned in nature whereas the latter can be planned, but it is scarcely avoidable in a social context (Schicks, 2013a). Large lump-sum shocks take the form of large expenses, such as marriage of a family 
member or close relative, child birth, and family ceremonies such as ear piercing or a puberty (coming of age) ceremony. In a survey carried out among poor rural households in the southern Arcot region of the Indian state of Tamil Nadu, focusing on household socioeconomic characteristics and borrowing practices, ceremonies were found to be the most important cause associated with borrower overindebtedness, highlighting the influence of planned lump-sum non-discretionary expenditure of the household on indebtedness (Guérin and others, 2011; Guérin, Morvant-Roux and Villarreal, 2013).

Regarding household expenditures, the acceptable argument about a priory causality can be, as borrowing increases, expenses of the household also increase. The recent behavioural research among microcredit borrowers provides reason to suspect otherwise. Two behavioural biases, scarcity and present based preference, are found to greatly influence the borrower response towards microfinance and thus act as significant forces on the demand side (Mullainathan and Shafir, 2013). The task of making day-to-day spending decisions in the face of scarcity and volatility of income sources consumes a significant cognitive band width available to the poor people. This results in a tunnelled focus in managing their immediate scarcity, which, in turn, translates into a present preference for cash to meet the immediate and important needs. Accordingly, scarcity created by severe limitation in available resources and importance, and immediacy of household expenses can lead to increased borrowing. Though there are no studies examining the direct influence of household expenditure on borrowing outcomes, Schicks (2013a) has found a significant association between non-productive uses of a loan and overindebtedness.

Therefore, the hypotheses on borrower related factors can be the following:

H2a: Household income will be negatively and significantly associated with overindebtedness.

H2b: Value of household assets will be positively and significantly associated with overindebtedness.

H2c: Planned lump-sum non-discretionary expenditures shocks faced by the borrower households during the previous 12 months will be positively and significantly associated with overindebtedness.

H2d: Recurring and unavoidable household expenses of the borrower households will be positively and significantly associated with overindebtedness.

Studies examining the impact of microfinance participation have also noted the increase in the level of indebtedness resulting from programme participation (Banerjee and others, 2015; Pitt and Khandker, 1998). The analysis conducted by Khandker, Faruqee and Samad (2014) shows that various household-level programme participation variables of the borrower households are found to be unequivocally associated 
with indebtedness outcomes of the households. Indirect evidence for size of the loans having a negative impact on borrowing outcomes is also indicated in Godquin (2004) and Sharma and Zeller (1997). Apart from programme participation, the role of multiple source loans in triggering a repayment crises has been widely observed in the context of microfinance (Krishnaswamy, 2007; Puliyakot and Pradhan, 2015).

One of the allegations against microfinance institutions leading up to a crisis in the state of Andhra Pradesh ${ }^{1}$ in India in 2006 is the charging of exorbitant rates of interest by the microfinance institutions operating in the state. Not only that they charge absolutely high interest rates (upwards of 20 per cent), but their practices, which included forced savings, applying a flat rate method and adding service and other charges, over and above the annual interest rate, further exacerbates the cost. This is leading to an overall high cost of borrowing for the poor, making microfinance institutions' rates appear to be almost usurious (Shylendra, 2006). Using a sample of borrowers from Ghana, Mensah (2013) finds that there is a significant relationship between interest rates and borrower defaults. In addition, Abbink, Irlenbusch and Renner (2006) and Hulme (2007) confirm the negative relationship between high borrowing cost and adverse borrower outcomes in the context of microfinance.

Contrary to the assumptions in theoretical literature on microfinance, not all microfinance loans are used for productive purposes. Karlan and Zinman (2011) find no evidence of increasing business investments as a result of expansion of microcredit access to second generation borrowers (individual liability loans) in the outskirts of Manila. Instead, the authors observe a diffused effect, with substitution away from labour and into education and substitution away from insurance even as overall access to risk-sharing mechanisms increases. Such diffused effects are also observed by Banerjee and others (2015) in a similar study in the state of Andhra Pradesh in India. At least in the immediate future, such borrowings may put a strain on the finances of the borrowing households. This may be because the view in some studies, such as those conducted by Vogelgesang (2003) and Schicks (2013a), consider nonproductive loans as a risk factor on the borrowing outcomes of the household.

Accordingly, the hypotheses on lender-related factors can be the following:

H3a: Total amount of loans contracted by the borrower from microfinance institutions will be positively and significantly associated with the borrower's level of overindebtedness.

Pursuant to the allegations of unethical lending practices and coercive collection practices employed by many microfinance lenders, the state government of Andhra Pradesh enacted a law referred to as the Andhra Pradesh Microfinance Institutions (regulation of money lending) Act in October 2010. As a consequence, microfinance lenders faced severe deterioration in lending portfolios and substantial decrease in new lending. For more details, please see Ghate (2007). 
H3b: Total amount of loans contracted from informal sources, such as money lenders, friends and relatives, will be positively and significantly associated with the borrower's level of overindebtedness.

H3c: Multiple source loans (number of credit arrangements) contracted by the borrower will be positively and significantly associated with overindebtedness.

H3d: Rates of interests and other charges imposed by microfinance institutions will be positively and significantly associated with overindebtedness.

H3e: Amount of loans used for consumption purposes will be positively and significantly associated with overindebtedness.

\section{Variable definitions}

External factors: On the dependant variables side, adverse economic shocks and uncertainty of income faced by the borrowing households represent external factors.

Adverse economic shocks: Both income and expenditure shocks jointly constitute the variable adverse economic shocks. For the purpose of capturing the variable, respondents are asked to narrate any such incidence of a loss of income or unforeseen heavy expenditure faced by the household during the 12 months period prior to the survey. Presence or absence of shocks are captured dichotomously.

Income uncertainty: A household's income is considered to be facing uncertainty if all the earning members in the household are casual labourers in urban areas, agricultural labourers in semi-urban areas or in a business or profession with a high seasonality element, such as making flower garlands. This variable is also captured as a dichotomous variable.

Borrower-related factors (demand side): Household annual income, annual expenses, household wealth in the form of asset holdings and planned lump-sum non-discretionary expenses constitute the variables studied under borrower relatedfactors.

Household income is the annual income of the household, earned by all the earning members of the household together. Annual household income has two components: monthly income; and lump-sum income earned annually, such as a bonus, scholarships or grants received from governments.

Annual household expenses include all the expenses incurred by the household during the past 12 months prior to the survey.

Planned lump-sum non-discretionary expenditures include expenses that are foreseeable in nature, such as college fees, daughter's marriage, and house construction expenses. 
Value of assets includes the aggregate value of all items of assets owned by the household that can have a resale value. Consumer durables are not counted as part of assets. This is in line with the treatment accorded to consumer durables in the National Sample Survey of indebtedness in India (India, Ministry of Statistics and Programme Implementation, 2014).

Lender-related factors (supply side): Total number of loans availed by the household from various credit sources, the respective sources of credit, microfinance institution fees and interest, and lending for consumption form part of lender-related factors.

Borrowings from microfinance institutions are represented by the aggregate amount borrowed by the respondent household from various microfinance institutions and continues to repay as on the date of the survey.

Loans from money lenders, friends and relatives: This variable includes loans from all informal sources, except gold loans from informal sources. As gold loans are fully collateralized, it does not obligate the borrower to make contractual periodical payments to the lender. Because of the accumulation of interest if the loan outstanding equates with the market value of gold, the lender enforces collateral. As there are no cash outflows on account of the loan, it does not affect the dependant variable either. Accordingly, the exclusion forms the variable.

Number of credit arrangements represents the number of loans availed by the household from various sources. It serves as a direct measure of multiple loans.

Microfinance institutions fees and interest is the weighted average fees and interest that the household has to pay in the current loan cycle to different microfinance institutions from whom it has borrowed. Most households have borrowed from more than one microfinance institution with different annual percentage rates. Effective annual percentage rates, including different fees and other incidental charges charged by different microfinance institutions are reported by MF Transparency (www.mftransparency.org) and are available in the public domain.

Lending for consumption. End-use purposes of the loans are captured by asking how the loan proceeds are actually spent by the households, irrespective of the stated purpose to the lending agency. Loans not used for either income generation purposes or asset creation purposes, such as buying gold or real estate, are considered as consumption loans. Consumption loans are considered under the lender-related category because the regulations and theory supporting microfinance lending do not condone lending by microfinance institutions for consumption purposes. Despite this, microfinance institutions' acquiescence to the widespread usage of loans for consumption purposes can only be attributed to the growth imperatives of the lenders, making it a supply-driven factor. This has contributed to a large divergence between the stated purpose and actual utilization of the loan at the borrower level (Karlan and Zinman, 2011). 
Demographic factors: Demographic factors included in the study are size of the household, age and education of the household head, occupational profile of the household head and dependants' ratio of the household. Size of the household is measured by number of people who permanently stay in a homestead. Education of the household head is measured as a three-level ordinal variable consisting of primary school and below, up to completion of secondary school and above secondary school. Occupational profile has three nominal categories, consisting of business or self-employed households, regular wage or salaried households and casual labourers. Categorization of the household is carried out on the basis of the occupational profile of the chief earner of the family.

\section{Empirical model for estimation}

As the empirical analysis is performed by classifying borrowers into two categories, overindebted and not overindebted borrowers, the dependant variable assumes a categorical nature. Accordingly, logit models of regression are used, as they are a more appropriate specification than ordinary least squares when the dependant variable involved is categorical and the assumption of normality is violated. For a linear combination of explanatory variables, logit models ascertain the probability of an outcome variable of interest. In the present study, the specific problem requires ascertaining the probability (odds) that a household will fall in a certain category of indebtedness, given a linear combination of explanatory variables.

For a binary outcome variable, a binary logistic regression model is fitted in which a set of regression coefficients are estimated that explains the probability of a binary outcome of interest, which is in the form:

$$
Y=\ln \frac{\text { Prob(Event) }}{1-\operatorname{Prob}(\text { Event })}=\alpha+\beta_{1} X+\beta_{2} m+\beta_{3} n+\beta_{4} p+\varepsilon
$$

Where:

$$
\begin{aligned}
& Y=\log \text { odds of a household being overindebted; } \\
& \mathrm{X}=\text { a vector of external factors; } \\
& \mathrm{m}=\mathrm{a} \text { vector of borrower-related factors; } \\
& \mathrm{n}=\text { a vector of lender-related factors; and } \\
& \mathrm{p}=\text { demographic factors; }
\end{aligned}
$$

as defined in the previous section. 


\section{SAMPLE, DATA AND FINDINGS}

The methodology used to address the main research questions is a primary sample survey among microfinance borrowers conducted between June 2015 and December 2015. The respondent set constitutes borrowers from microfinance institutions, who have been borrowing from such institutions for at least the past three years. The sampling technique is a simple random sampling from two districts in the state of Tamil Nadu in southern India. South India is the most rapidly growing microfinance market in the Indian subcontinent (Sa-Dhan, 2015). Within South India, Tamil Nadu is one of the largest and most rapidly growing microfinance markets in India. Within the state of Tamil Nadu, two districts are selected for the specific characteristics of the districts and their relevance for the microfinance industry. The choice of urban and semi-urban borrowers of microfinance is made in line with the shifting focus of Indian microfinance from predominantly rural-focused lending to more rapid coverage of the urban areas in the recent past, as reported by Sa-Dhan, an association of development finance institutions in India.

\section{Table 1. Sample statistics}

\begin{tabular}{|c|c|c|c|}
\hline Parameter & Description & Mean & $\begin{array}{l}\text { Standard } \\
\text { deviation }\end{array}$ \\
\hline Overindebtedness & $\begin{array}{l}1=\text { overindebted } \\
0=\text { not overindebted }\end{array}$ & 0.57 & 0.496 \\
\hline Total value borrowed & $\begin{array}{l}\text { Total value of loans borrowed } \\
\text { from all sources }\end{array}$ & 105993.57 & 109003.86 \\
\hline Adverse economic shocks & Yes $=1$, No $=0$ & 0.50 & 0.50 \\
\hline Income uncertainty & Yes $=1$, No $=0$ & 0.59 & 0.49 \\
\hline Annual income & In Indian rupees & 169653.39 & 95284.45 \\
\hline Asset holding & In Indian rupees & 254540.95 & 29914.68 \\
\hline $\begin{array}{l}\text { Planned lump-sum non- } \\
\text { discretionary expenditures }\end{array}$ & In Indian rupees & 40213.10 & 68635.65 \\
\hline $\begin{array}{l}\text { Annual household } \\
\text { expenses }\end{array}$ & In Indian rupees & 163723.64 & 102692.74 \\
\hline $\begin{array}{l}\text { Total microfinance } \\
\text { institutions borrowing }\end{array}$ & In Indian rupees & 42922.62 & 25928.37 \\
\hline $\begin{array}{l}\text { Loans from money lenders, } \\
\text { friends and relatives }\end{array}$ & In Indian rupees & 27570.00 & 72692.00 \\
\hline $\begin{array}{l}\text { Total number of loans per } \\
\text { household }\end{array}$ & Absolute number & 3.09 & 1.35 \\
\hline $\begin{array}{l}\text { Microfinance fees and } \\
\text { interest }\end{array}$ & In Indian rupees & 11200.48 & 5115.46 \\
\hline Lending for consumption & In Indian rupees & 70303.10 & 70246.37 \\
\hline
\end{tabular}


Table 1. (continued)

\begin{tabular}{|c|c|c|c|}
\hline Parameter & Description & Mean & $\begin{array}{l}\text { Standard } \\
\text { deviation }\end{array}$ \\
\hline Household size & Number of members & 3.79 & 1.20 \\
\hline Dependant ratio & $\begin{array}{l}\text { No. of non-working members } \\
\div \text { No. of working members }\end{array}$ & 1.44 & 1.32 \\
\hline Household head age & Age in years & 43.47 & 10.79 \\
\hline Household head education & $\begin{array}{l}\text { Up to } 5 \text { years }=1,5 \text { to } 10 \\
\text { years }=2, \text { above } 10 \text { years }=3\end{array}$ & 1.79 & 0.62 \\
\hline $\begin{array}{l}\text { Occupation: business/ } \\
\text { self-employed }\end{array}$ & Yes $=1$, No $=0$ & 0.14 & 0.35 \\
\hline $\begin{array}{l}\text { Occupation: regular wage/ } \\
\text { salaried employee }\end{array}$ & Yes $=1$, No $=0$ & 0.27 & 0.44 \\
\hline $\begin{array}{l}\text { Occupation: casual } \\
\text { labourer }\end{array}$ & Yes $=1$, No $=0$ & 0.59 & 0.49 \\
\hline $\mathrm{N}$ & & 210 & \\
\hline
\end{tabular}

Table 1 shows the sample statistics of the variables mentioned above. Fifty-seven per cent of borrowers were living below the poverty line level of income after meeting the loan repayment commitments. The national average of people living below the poverty line during the year 2011/12 was 21.9 per cent (India, 2018). In the table, the measure of total borrowing is the aggregate value at disbursal of all the outstanding loans at the date of survey.

Fifty per cent of the respondent households reported to have faced some form of income or expenditure shocks during a period of one year prior to the survey. This observation is more or less corroborated by the incidence of income uncertainty, which was also high, at the level of 59 per cent. Seen in the context of occupational profile, in which 59 per cent of the respondents fell in the category of casual labourers, the high incidence of income uncertainty appeared to be supported by other sample characteristics.

A lion's share of annual income for the sample respondents in the present study is derived from the monthly incomes only. The observed figure of approximately Rs 170,000 per annum works out approximately to Rs 15,000 per month, or an average of Rs 500 per day per household. This is well above the average wage levels observed for urban workers in the latest National Sample Survey of Households, and hence will not affect the conclusions of the study even if there are measurement errors. Value of asset holding exhibit high levels of volatility. Planned lump-sum non-discretionary expenditures of approximately Rs 40,000 is consistent with the annual income and shows the conservative nature of the households. Annual household expenses of 
approximately Rs 163,000 is below the annual income of Rs 170,000 , but it shows the meagre surplus available with the borrowing households after meeting the necessary household commitments. This is strongly supportive of the arguments put forward by Guérin, Roesch and Kumar (2011) and Mullainathan and Shafir (2013) that scarcity can be a powerful force pushing people towards excess borrowing.

Among the lender-related factors, average microfinance institution borrowing of approximately Rs 42,000 is well within the regulatory limits of Rs 50,000 , which was prevalent at the time of the survey. One hundred and eleven households in the sample have reported to have borrowings from more than one microfinance institution, out of which 88 have only two loans outstanding. The number of loans for the remaining 23 households range from three to five. This shows that violation of regulatory norm, though not completely absent, does not also occur in a large scale. The exceptions are mainly because of multiple borrowers in the same households, simultaneous memberships of self-help groups and joint liability microfinance institutions groups, and the existence of both internal and bank-linked loans in the case of a handful of self-help group clients.

The average value of consumption loans is much greater than that for microfinance institution loans, implying that a good share of credit from sources other than from microfinance institutions are directed towards consumption purposes. This is consistent with the narrow difference observed between household income and household expenses, as households facing a shortage of income will be forced to avail credit to bridge the gap. The average number of loans, at 3.09, indicates that apart from microfinance institution loans, most borrowers have accessed at least one more source of loan, point to the presence of multiple borrowing. Average microfinance institution fees and interest of approximately Rs 11,200 is consistent with the average borrowing size of Rs 42,000 , implying an annual percentage rate of approximately 26.67 per cent.

Demographic features of the sample show that a representative borrower profile has an average age of below 45 , with average education levels between the primary and secondary levels and the average occupational profile tending towards casual labourers. Average educational attainment of 1.79 shows that most of the sample respondent household heads have not completed secondary school education, and have dropped out of schools between the primary and secondary levels. This goes well with another sample feature of the employment profile of the respondent households. The chances of a household head of the borrower household being a regular wage or salaried employee is only 29 per cent, whereas the chances for being a casual labourer is 59 per cent. 


\section{RESULTS AND DISCUSSION}

Based on the above sample features, below is the result and a discussion of the logistic regression analysis of the binary dependant variable, overindebtedness.

Table 2. Result of binary logistic regression on overindebtedness

\begin{tabular}{|c|c|c|}
\hline Parameter & Coefficient & Odds ratio \\
\hline \multirow[t]{2}{*}{ Adverse economic shocks } & $1.709^{\star \star *}$ & 5.523 \\
\hline & $(0.601)$ & \\
\hline \multirow[t]{2}{*}{ Income uncertainty } & -0.298 & 0.742 \\
\hline & $(0.614)$ & \\
\hline \multirow[t]{2}{*}{ Annual household income } & $-6.665^{\star \star \star}$ & 0.001 \\
\hline & $(1.197)$ & \\
\hline \multirow[t]{2}{*}{ Household asset holding } & 0.082 & 1.085 \\
\hline & $(0.096)$ & \\
\hline \multirow[t]{2}{*}{ Panned lump-sum non-discretionary expenses } & -0.002 & 0.998 \\
\hline & $(0.068)$ & \\
\hline \multirow[t]{2}{*}{ Annual household recurring expenses } & -0.669 & 0.512 \\
\hline & $(0.913)$ & \\
\hline \multirow[t]{2}{*}{ Total microfinance borrowing } & -0.132 & 0.876 \\
\hline & $(0.104)$ & \\
\hline \multirow[t]{2}{*}{ Total borrowings from money lenders, friends and relatives } & $0.412^{\star \star *}$ & 1.510 \\
\hline & $(0.117)$ & \\
\hline \multirow[t]{2}{*}{ Total number of loans per household } & $1.397^{\star \star \star}$ & 4.043 \\
\hline & $(0.306)$ & \\
\hline \multirow[t]{2}{*}{ Microfinance institution fees and interest } & -0.702 & 0.496 \\
\hline & $(0.651)$ & \\
\hline \multirow[t]{2}{*}{ Total value of consumption loans } & 0.046 & 1.047 \\
\hline & $(0.063)$ & \\
\hline \multirow[t]{2}{*}{ Household size } & $1.900^{\star \star \star}$ & 6.686 \\
\hline & $(0.446)$ & \\
\hline \multirow[t]{2}{*}{ Dependant ratio } & $0.630^{\star *}$ & 1.878 \\
\hline & $(0.317)$ & \\
\hline \multirow[t]{2}{*}{ Household head age } & $0.060^{\star \star}$ & 1.062 \\
\hline & $(0.030)$ & \\
\hline \multirow[t]{2}{*}{ Household head education } & $1.248^{\star \star}$ & 3.483 \\
\hline & $(0.486)$ & \\
\hline
\end{tabular}


Table 2. (continued)

\begin{tabular}{lcc}
\hline \multicolumn{1}{c}{ Parameter } & Coefficient & Odds ratio \\
\hline Occupation: business/self-employed & 0.856 & 2.354 \\
Occupation: casual labourer & $(0.930)$ & \\
& 0.543 & 1.721 \\
Cox and Snell R square & $(0.660)$ & \\
Negelkerke R square & 0.581 & \\
$\mathrm{~N}$ & 0.781 & \\
\hline
\end{tabular}

Note: Standard errors in parenthesis. ${ }^{*},{ }^{\star \star},{ }^{* \star \star}$ denote significance at 10 per cent, 5 per cent and 1 per cent, respectively.

Chi-square test of the model and Hosmer and Lemeshow test indicate good model fit with $\mathrm{P}$ values of .00 and .969 , respectively. In approximately 88.6 per cent of the cases, the model's predictions are consistent with the data set. Variables entered into the model with significance include variables from all three factors, namely external, borrower and lender-related factors. Among the demographic control factors, household size, dependant ratio, age and education of the household head are significant.

Under environmental factors, adverse economic shocks are statistically significant at the 1 per cent level. Income uncertainty is not found to be significant. The coefficient of adverse economic shocks suggests that a household that had faced an economic shock during the immediately preceding twelve months is more than 5.5 times as likely to be overindebted than a household not subjected to such misfortunes.

On the borrower-related factors, annual income is statistically significant under the 1 per cent level. It has to be noted that the other variables, such as value of assets and planned lump-sum non-discretionary expenditures, do not exert any influence over pushing a household to overindebtedness, suggesting that the outcome may not be the result of conscious actions by the households. Instead, in the course of managing day-to-day finances, a poor household may be forced to borrow to meet liquidity requirements, which over a period of time may push the household to a state of overindebtedness.

The supply side factors that are found to influence overindebtedness significantly are the total number of credit arrangements the household has contracted and the total amount of borrowings from informal sources, which include money lenders, friends and relatives. The odds ratio for the total number of credit arrangements suggests that, within the sample, one more loan taken by the household from any sources will increase the likelihood of the household being overindebted by about 
four times. Many crises involving the microfinance industry in recent years in many of its growing markets is attributed to the practice of multiple lenders targeting the same borrowers. This finding further supports the suspected link between multiple borrowings and later repayment crises through the channel of overindebtedness.

Also noteworthy is the finding that an increase in borrowings from informal sources by Rs 10,000 raises the likelihood of a household being overindebted by 1.5 times is not applicable for borrowing from microfinance institutions. Recent regulatory interventions in the industry in response to crises experienced in certain states of India, especially in the form of regulating the maximum number of loans and the amounts of credit that can flow to each borrower, and the active role played by credit information bureaus could have contributed to this finding in no small measures. This, however, has to be seen in the context of the significance of other informal sources of borrowing in influencing overindebtedness. Despite the rapid growth of microfinance over the past decade, the marginalization of informal sources of credit, which often come with punitive terms, appears to be limited. These findings with respect to the environmental, lender-related and borrower-related factors influencing overindebtedness are broadly in line with the extant literature on the subject (Schicks, 2013a; Guérin, Morvant-Roux and Villarreal, 2013; Khandker, Faruqee and Samad, 2014).

Because the estimates of the poverty line level of expenditure continue to be highly debatable, the results are tested with a different poverty line estimated by the World Bank for the purposes of international comparison. Using purchasing power paritybased exchange rates, the World Bank has estimated the international poverty line at $\$ 1.90$ per day based on 2011 prices (World Bank, 2014). The Indian rupee equivalent of this is Rs 27.87, using a purchasing power parity-based exchange rate of Rs 14.67 per dollar. Adjusted for inflation between 2011 and 2015, which is the survey date, this translates into Rs 38.46 per capita per day. Results of the regression using this poverty threshold are given in table 3 . As per this measure, approximately 31 per cent of the microfinance borrowers are overindebted. While the Chi-square test for the model shows a p-value of .000 , the Hosmer and Lemeshow test shows a p-value of .001, giving conflicting results on model fit. As seen from the table, however, the results converge on many parameters, including, for example, household income, number of credit arrangements and loans from money lenders, friends and relatives.

One key difference in this regression is the negative influence of annual household living expenses on the odds of household being overindebted. With every Rs 100,000 increase in the annual living expenses, the odds ratio for being overindebted falls by approximately 92 per cent. Contrary to the hypothesis, this result may be suggestive of households cutting down on living expenses as a result of increasing overindebtedness and may point to the material sacrifices the overindebted families may go through. 
This has been considered as one of the material sacrifices overindebted families undergo, in studies of overindebtedness measured on the basis of sacrifices (Schicks, 2013a; Ray, Mahapatra and Nath, 2019).

Table 3. Results of binary logistic regression on overindebtedness, using World Bank estimates of poverty line

\begin{tabular}{|c|c|c|}
\hline Parameter & Coefficient & Odds ratio \\
\hline \multirow[t]{2}{*}{ Adverse economic shocks } & $1.070^{\star \star}$ & 2.915 \\
\hline & $(0.511)$ & \\
\hline \multirow[t]{2}{*}{ Income uncertainty } & 0.335 & 1.398 \\
\hline & $(0.580)$ & \\
\hline \multirow[t]{2}{*}{ Annual household income } & $-4.573^{\star \star \star}$ & 0.010 \\
\hline & $(0.967)$ & \\
\hline \multirow[t]{2}{*}{ Household asset holding } & 0.114 & 1.121 \\
\hline & $(0.078)$ & \\
\hline \multirow[t]{2}{*}{ Panned lump-sum non-discretionary expenses } & 0.043 & 1.044 \\
\hline & $(0.0544)$ & \\
\hline \multirow[t]{2}{*}{ Annual household recurring expenses } & $-1.711^{\star \star}$ & 0.181 \\
\hline & $(0.863)$ & \\
\hline \multirow[t]{2}{*}{ Total microfinance institutions borrowing } & -0.014 & 0.986 \\
\hline & $(0.170)$ & \\
\hline \multirow[t]{2}{*}{ Total borrowings from money lenders, friends and relatives } & $0.080^{*}$ & 1.083 \\
\hline & $(0.042)$ & \\
\hline \multirow[t]{2}{*}{ Total number of loans per household } & $1.642^{\star \star \star}$ & 5.165 \\
\hline & $(0.340)$ & \\
\hline \multirow[t]{2}{*}{ Microfinance institutions fees and interest } & -1.166 & 0.311 \\
\hline & $(0.779)$ & \\
\hline \multirow[t]{2}{*}{ Total value of consumption loans } & $0.136^{\star \star \star}$ & 1.146 \\
\hline & $(0.052)$ & \\
\hline \multirow[t]{2}{*}{ Household size } & $0.993^{\star \star \star}$ & 2.699 \\
\hline & $(0.294)$ & \\
\hline \multirow[t]{2}{*}{ Dependant ratio } & 0.322 & 1.380 \\
\hline & $(0.265)$ & \\
\hline \multirow[t]{2}{*}{ Household head age } & $0.080^{* \star *}$ & 1.083 \\
\hline & $(0.028)$ & \\
\hline \multirow[t]{2}{*}{ Household head education } & $1.809^{\star \star \star}$ & 2.971 \\
\hline & $(0.492)$ & \\
\hline
\end{tabular}


Table 3. (continued)

\begin{tabular}{lcc}
\hline \multicolumn{1}{c}{ Parameter } & Coefficient & Odds ratio \\
\hline Occupation: business/self-employed & 0.610 & 1.840 \\
& $(0.863)$ & \\
Occupation: casual labourer & -0.546 & 0.579 \\
& $(0.624)$ & \\
Cox and Snell R square & 0.581 & \\
Negelkerke R square & 0.781 & \\
$\mathrm{~N}$ & 210 & \\
\hline
\end{tabular}

Note: Standard errors in parenthesis. *, ${ }^{\star \star},{ }^{* \star \star}$ denote significance at 10 per cent, 5 per cent and 1 per cent, respectively.

\section{CONCLUSIONS AND POLICY IMPLICATIONS AND LIMITATIONS}

In the present study, the concept of overindebtedness among microfinance borrowers is analysed using a unique measure of overindebtedness, hitherto unused in the literature. The main findings of the study point to the possibility that households with low incomes, when hit by economic shocks, become highly vulnerable to the situation of overindebtedness. Easy availability of credit from many informal sources act as supply side forces aiding the outcome. This strongly suggests the need to prioritize policy intervention in favour of providing income-generating activities, rather than ensuring availability of credit to the targeted group. Size and cost of microfinance loans not being significant factors affecting the state of overindebtedness may be suggestive of the sufficiency of access regulations implemented in the wake of the past crises in India. Given the negative relationship observed in the regression using the World Bank poverty line between household expenses and overindebtedness, the material sacrifices undertaken by overindebted households can be an area of future research.

This study is conducted in a limited geographic area with limited participants because of time and resource constraints. In addition, poverty line level of income which is used for identification of dependant variable has certain weaknesses, such as likely measurement errors present in the expenditure data used and disproportionately large representation of affluent households in the sample size (Raveendran, 2016). Though the problem of overindebtedness is studied here in the specific context of microfinance, borrowers who are not beneficiaries of microfinance can also be affected by issues related to excessive debt burden. Further studies in overindebtedness may address these limitations. 


\section{REFERENCES}

Abbink, Klaus, Bernd Irlenbusch, and Elke Renner (2006). Interest rates in group lending: a behavioral investigation. Pacific Economic Review, vol. 11, No. 2, pp. 185-199.

Al Mamun, Abdullah, and others (2011). Examining the critical factors affetcting the repayment of microcredit provided by Amanah Ikhthiyar Malaysia. International Business Research, vol. 4, No. 2, pp. 93-103.

Banerjee, Abhijit, and others (2015). The miracle of microfinance: evidence from a randomized evaluation. American Economic Journal: Applied Economics, vol. 7, No. 1, pp. 22-53.

Betti, Gianni, and others (2007). Consumer over-indebtedness in the EU: measurement and characteristics. Journal of Economic Studies, vol. 34, No. 2, pp. 136-156.

Bridges, Sara, and Richard Disney (2004). Use of credit and arrears on debt among low income families in the United Kingdom. Fiscal Studies, vol. 1, No. 25, pp. 1-25.

Centre for the Study of Financial Innovation (2012). Microfinance Banana Skins 2012. London.

Dickerson, A. Mechele (2008). Consumer over-indebtedness: a US perspective. Texas International Law Journal, vol. 43, pp. 135-159.

Disney, Richard, Sarah Bridges, and John Gathergood (2008). Drivers of over-indebtedness: report to the Department for Business Enterprise and Regulatory Reform. Essex, United Kingdom: Institute for Social and Economic Research, University of Essex.

(2010). House price shocks and the household indebtedness in the United Kingdom. Economica, vol. 77, No. 307, pp. 472-496.

European Commission (2008). Towards a Common Operational European Definition of OverIndebtedness. Brussels.

Frederick, Shane, George Loewenstein, and Ted O'Donoghue (2002). Time discounting and time preference: a critical review. Journal of Economic Literature, vol. 40, No. 2, pp. 351-401.

Ghate, Prabhu (2007). Consumer protection in Indian microfinance: lessons from Andhra Pradesh and the microfinance bill. Economic and Political Weekly, vol. 42, No. 13, pp. 1176-1184.

Godquin, Marie (2004). Microfinance repayment performance in Bangladesh: how to improve the allocation of loans by MFIs. World Development, vol. 32, No. 11, pp. 1909-1926.

Guérin, Isabelle, Soléne Morvant-Roux, and Magdalena Villarreal (2013). Microfinance, Debt and Over-Indebtedness: Juggling with Money. New York: Routledge.

Guérin, Isabelle, Marc Roesch, and Venkatasubramanian Kumar (2011). The social meaning of overindebtedness and credit worthiness in the context of poor rural South India households (Tamil Nadu). RUME Working Papers Series No. 2011-1. Paris: IRD.

Haas, Oliver (2006). Overindebtedness in Germany. Social Finance Working Paper, No. 44. Geneva: International Labor Organization.

Hulme, David (2007). Is microdebt good for the people? A note on the darker side of microfinance. In What is Wrong with Microfinance, Thomas Dichter and Malcom Harper, eds. Rugby, Warwickshire, United Kingdom: Practical Action Publishing. 
India, Ministry of Statistics and Programme Implementation (2014). Key Indicators of Debt and Investments in India. NSS 70th Round, 2013. Available at www.mospi.gov.in/sites/default/ files/publication_reports/KI_70_18.2_19dec14.pdf.

(2018). India in Figures 2018. New Delhi: Central Statistics Office.

India Planning Commission (2014). Report of the Expert Group to Review the Methodology for Measurement of Poverty. Working Papers. New Delhi.

Karlan, Dean, and Jonathan Zinman (2011). List randomization for sensitive behavior: an application for measuring use of loan proceeds. Journal of Development Economics, vol. 98, No. 1, pp. $71-75$.

Kempson, Elaine (2002). Over-indetedness in Britain. Report to the Department of Trade and Industry, Great Britain. Available at www.pfrc.bris.ac.uk/Reports/Overindebtedness_Britain.pdf.

Khalily, Baqui, and Rushad Faridi (2011). Multiple Memberships (Overlapping) in Microcredit Markets of Bangladesh. Dhaka: Institute of Microfinance \& Palli Karma Sahayak Foundation.

Khandker, Shahidur, Rashid Faruqee, and Hussain Samad (2014). Are microcredit borrowers in Bangladesh over-indebted? Institute of Microfinance Working Paper, No. 26. Washington, D.C.: World Bank.

Krishnaswamy, Karuna (2007). Competition and multiple borrowing in the Indian microfinance sector. Working Paper. Centre for Micro Finance, Institute for Financial Management and Research. Available at www.findevgateway.org/sites/default/files/publications/files/ mfg-en-paper-competition-and-multiple-borrowing-in-the-indian-microfinance-sectorsep-2007.pdf.

Mader, Philip (2013). Rise and fall of microfinance in India: Andhra Pradesh crisis in perspective. Strategic Change, vol. 22, No.1-2, pp. 47-66.

Mani, Anandi, and others (2013). Poverty impedes cognitive function. Science, vol. 341, No. 6149, pp. 976-980.

Maurer, Klaus, and Justyna Pytkowska (2011).Indebtedness of microcredit clients in Bosnia and Herzegovina: results from a comprehensive field study. Frankfurt, Germany: European Fund for Southeast Europe.

Mensah, Charles (2013). The relationship between loan default and repayment schedules in microfinance institutions in Ghana: a case study of Sinapi Aba Trust. Research Journal of Finance and Accounting, vol. 4, No. 19, pp. 165-175.

Microcredit Summit Campaign (2015). State of the campaign report . Washigton, D.C.

Mullainathan, Sendit, and Eldar Shafir (2013). Scarcity: Why Having Too Little Means So Much. New York: Times Books.

Oke, Joel, R. Adeyemo, and Mure Agbonlahor (2007). An empirical analysis of microcredit repayment in Southwestern Nigeria. Humanity and Social Sciences Journal, vol. 16, No. 4, pp. 63-74.

OXERA Consulting (2004). Are UK Households Overindebted? Oxford: U.K: Oxera.

Pitt, Mark, and Shahidur Khandker (1998). The impact of group based credit programs on poor households in Bangladesh: does the gender of participants matter? Journal of Political Economy, vol. 106, No. 5, pp. 958-996. 
Puliyakot, Sunil, and H. Pradhan (2015). Competition, multiple borrowing and over-indebtedness in microfinance: an empirical investigation. The Microfinance Review, vol. 7, No. 2, pp. 126-139.

Pytkowska, Justyna, and Sylvia Spannuth (2011). Indebtedness of microcredit clients in Kosovo. Frankfurt, Germany: European Fund for South East Europe.

(2012). The risk of over-indebtedness of microfinance clients in Azerbaijan. Frankfurt, Germany: European Fund for South East Europe.

Raveendran, G. (2016). A review of Rangarajan Committee report on poverty estimation. Indian Journal of Human Development, vol. 10, No. 1, pp. 85-96.

Ray, Sougata, Sushanta Mahapatra, and Shyam Nath (2019). Over-indebtedness and its drivers among microfinance borrowers in India. Economic and Political Weekly, vol. 54, pp. 47-54.

Reichert, Patrick (2018). A meta-analysis examining the nature of trade-offs in microfinance. Oxford Development Studies, vol. 46, No. 3, pp. 430-452.

Rowlinson, Karen, and Elaine Kempson (1994). Playing with Plastic: A Study of Credit Card Debt. London: Policy Studies Institute.

Sa-Dhan (2015). The Bharat Microfinance Report 2015. New Delhi.

Schelling, Thomas (1984). Self-command in practice, in policy, and in a theory of rational choice. The American Economic Review, vol. 74, No. 2, pp. 1-11.

Schicks, Jessica (2013a). Over - indebtedness in microfinance: an empirical investigation of related factors on the borrower level. World Development, vol. 54, No. C, pp. 301-324.

(2013b). The definition and causes of microfinance over-indebtedness: a customer protection point of view. Oxford Development Studies, vol. 41, Issue Supplement 1, pp. S95-S116.

Schicks, Jessica, and Richard Rosenberg (2011). Too much microcredit? A survey of the evidence on over-indebtedness. CGAP Occasional Paper, No. 19. Washington, D.C.: CGAP.

Sharma, Manohar, and Manfred Zeller (1997). Repayment performance in group based credit programs in Bangladesh: an empirical analysis. World Development, vol. 25, No. 10. pp. 1731-1742.

Shylendra, H. (2006). Microfinance institutions in Andhra Pradesh. Economic and Political Weekly, vol. 41, No. 20, pp. 1959-1963.

Stone, Bruce, and Rosalinda Maury (2006). Indicators of personal financial debt using a multidisciplinary behavioral model. Journal of Economic Psychology, vol. 27, No. 4, pp. 543-556.

Vogelgesang, Ulrike (2003). Microfinance in times of crisis: the effects of competition, rising indebtedness, and economic crisis on repayment behavior. World Development, vol. 31, No. 12, pp. 2085-2114.

Williams, Leonard (1985). Tunnel vision induced by a foveal load manipulation. The Journal of the Human Factors and Ergonomics Society, vol. 27, No. 2, pp. 221-227.

World Bank (2014). Purchasing Power Parities and Real Size of World Economies: A Comprehensive Report of the 2011 International Comparison Program. Washigton, D.C.: International Bank for Reconstruction and Development/World Bank. 